【報

\title{
溶接継手の疲労寿命に与える隅肉溶接止端形状の影響

\author{
EFFECT OF WELD TOE PROFILES ON FATIGUE STRENGTH \\ OF FILLET WELDED SPECIMENS
}

\author{
田垣徳 幸* - 近藤明雅** - 山田健太郎*** - 菊池 洋 一**** \\ By Noriyuki TAGAKI, Akimasa KONDO, Kentaro YAMADA \\ and Yoichi KIKUCHI
}

\section{1. まえがき}

リブ十字形隅肉溶接継手のように, 応力直角方向に隅 肉溶接をもつ継手では, 隅肉溶接の止端部に応力集中が 生じる.したがって，この継手が繰り返し応力を受ける と, その部分に疲れ亀裂が発生し, それが進展して破断 に至る.この種の継手の疲労挙動を詳細に検討するに は，隅肉溶接止端部の形状や，局部的な残留応力，あ るいは溶接による母材の材質変化などの多くの因子を評 価する必要がある。ところが，上述のような因子それぞ れが疲労挙動に及ぼす影響についても, これまでの研究 で明確にされてきたわけではなく，それらの因子が混在 する形の試験片での実験も，一般に難しい問題を含むと 思われる.

上記の因子のうち, 隅肉溶接止端形状が疲労寿命に及 ぼす影響については，止端形状が比較的容易に測定でき ることから研究が進んできている(6),7),11),16). 金属材料 技術研究所では, データシート作成のための疲れ試験 で，リブ厚と主板の比を変えた多数のリブ十字形隅肉 溶接継手を試験した ${ }^{6}$. この試験では, 疲れ試験に先だ ち, 止端形状をシリコンゴムで型取りし, 疲れ試験後, 亀裂発生点と思われる箇所の止端形状を測定した. さら にこの止端形状から, 応力集中係数 $K_{T}$ を計算して, 疲労寿命 $N_{f}$ との相関を求めている. その結果, 止端 形状のばらつき，すなわち $K_{T}$ のばらつきが $N_{f}$ の変 動となって現われており, 板厚の差が $K_{T}$ の差となっ てくることから, 試験に用いた因子のらちで, 板厚の因 子だけが $N_{f}$ に有意の差を与えることがわかった。 ま た本四公団では, リブ十字継手の大型疲労試験を行い,

* 正会員 工修 新日本製鉄（株）（前・名大大学院）

** 正会員 名城大学講師 (前・名大助手)

*** 正会員 $\mathrm{Ph} . \mathrm{D}$. 名古屋大学助教授

***** 正会員 工博 名古屋大学教授
寸法効果の影響, ビード形状のよい隅肉専用棒を使用し た場合の疲れ強さ等について検討し, 溶接止端形状を測 定し, 疲れ亀裂発生状況との関係についても調べてい $る^{16)}$.

この種の継手では, 疲れ亀裂の発生が隅肉溶接止端部 に限られることから, その部分の形状の改善, 材質の改 良, あるいは局部的な圧縮残留応力の導入によって, 疲 れ強さを改善できる. 隅肉溶接止端形状の $N_{f}$ に及ぼ す影響の研究は, 疲れ強さ向上法を検討するうえでも重 要である. 疲れ強さ向上法としては, 溶接止端部の切削 や研削による応力集中の軽隇(5),8),11),12)，ピーニング処 理 ${ }^{5,12)}$, 止端形状が滑らかになる 溶接棒を用いた溶接

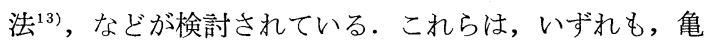
裂が発生すると思われる止端部を処理して， $N_{f}$ の向上 を期待しているものである.

上述の研究では, 一般に溶接止端形状が $N_{f}$ に及ぼ す影響について実験的に検討されている.ところが, こ の $N_{f}$ は, 疲れ亀裂が発生してある大きさに達するま での 過程 $N_{c}$ と, その亀裂が進展して破断に至る過程 $N_{p}$ とに分けることができる ${ }^{3), 9)}$. 止端形状の影響を, この両者を区別して検討している例は少ない ${ }^{11)}$. 山田ら は, 先にリブ十字形隅肉溶接継手に発生する疲れ亀裂の 進展挙動を浸透性のよい塗料でマークし, その進展挙動 を明らかにした 法を応用し, おもに亀裂形状のばらつきを考慮した。隅 肉溶接止端部から疲れ亀裂が発生するような場合には, 実際に亀裂が発生した点の止端形状が問題となるので, これと $N_{c}$ と $N_{p}$, あるいは龟裂形状の変化などとの相 関性を調查してゆく必要があるものと思われる.

そこで, 本研究では, リブ十字形隅肉溶接継手の亀裂 発生点の止端形状を測定し, 疲れ亀裂進展挙動との関係 について調查した. 止端形状の測定には, シリコンゴム で型取りし, それを細分割して, その側面から止端角や 止端半径を測定する方法を用いた。 また，発生した亀裂 
の進展挙動を把握するため, 塗料によるマーキングやビ 一チマーク法を併用した. この結果を用いて, 止端形状 が $N_{p}$ に及ぼす影響を検討した. この $N_{p}$ は, 破壊力 学の手法を用いても計算できるので, 実験結果をもとに 計算から求めた $N_{p}$ と比較するとともに, $N_{c}=N_{f}-N_{p}$ の関係を用いて $N_{c}$ に及ぼす止端形状の影響についても 検討した。

\section{2. 疲れ試験および止端形状の測定}

\section{(1) 疲れ試験の概要}

リブ十字形隅肉溶接試験片の材質および試験片の様子 を Table 1 に, 機械的性質, 化学成分を Table 2 に 示す. 試験片は, 板厚 $10 \mathrm{~mm}$, 幅 $25 \mathrm{~mm}$ の引張試験片 にリブが隅肉溶接されており，一般にプレートガーダの 垂直補剛材や箱析のダイヤフラムの隅肉溶接などの疲れ 強さ確認試験に用いられるものである.

試験片のらち, T 5 と T 8 は, 軸方向に圧縮塑性加 工を行った SMA 50 材に, あとでリブを手溶接したも ので，それぞれ $5 \%$ と 8\% の塑性加工を施してある.

T0 は塑性加工をしていない.この場合, 圧縮塑性加工 した後にリブを溶接したため, 圧縮塑性加工が $N_{f}$ に 与える影響はみられず，本報文では他の試験片と同等に 扱った. $\mathrm{N}$ は, 東京都計画街路放射 31 号線の新大橋の 架け替え事業に使用された仮橋の垂直補剛材を含む腹板 から切り出した試験片である.この橋は, SMA 50 耐候 性鋼を用いた無叙装橋梁で，実験に用いるまで約 5 年間 屋外に放置された．桁は空地に並列して置かれていた.

Table 1 Type and Origin of Transverse Fillet Welded Specimen Tested.

\begin{tabular}{|c|c|c|}
\hline Specimen & Steel & Comment \\
\hline $\begin{array}{ll}\text { T } & 0 \\
\text { T } & 5 \\
\text { T } & 8\end{array}$ & SMA 50 & $\begin{array}{l}\text { Stiffener specimens, as-welded. } 5 \% \text { and } \\
8 \% \text { compressive pre-strained before } \\
\text { welding ribs. }\end{array}$ \\
\hline $\mathrm{N}$ & SMA 50 & $\begin{array}{l}\text { Cut-out from the Shin-Ohashi bridge. } \\
\text { Unpainted and exposed to air for about } \\
5 \text { years. }\end{array}$ \\
\hline $\begin{array}{l}\text { E } 3 \\
\text { E } 4 \\
\text { E } 6\end{array}$ & SM 50 & $\begin{array}{l}\text { With controled fillet weld toe angle of } \\
\theta=30^{\circ}, 45^{\circ} \text { and } 60^{\circ} \text {, respectively. } \\
\text { As-welded. }\end{array}$ \\
\hline
\end{tabular}

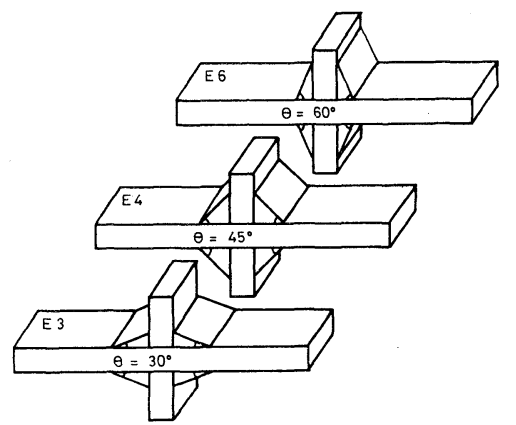

Fig. 1 Fillet welded specimens with various fillet weld toe angles. (E-series specimens)

試験片を採取した部分では，雨水がたまることもなく， 耐候性鋼の無塗装使用に関しては，おおむね良好な環境 と思われる．鋼材表面は，耐候性鋼特有の安定したさび 層に覆われていた， T と $\mathrm{N}$ とは, 隅肉止端形状に特別 の配慮をして抢らず，通常の橋梁の溶接条件下で溶接さ れた隅肉の形状をもつものと思われる。

さらに，溶接止端形状を意識的にコントロールした試 験片 $\mathrm{E}$ を製作した。これは, 治具を用いて溶接箇所の傾 きを変え，止端角 $\theta$ が，およそ $30^{\circ} ， 45^{\circ}, 60^{\circ}$ になるよ らにしたもので, 鉄粉低水素系 (JIS D 5000) の溶接棒 を用いて手溶接した.この試験片の様子を，Fig. 1 に 示す.

\section{（2）疲れ試験方法と亀裂発生点の確認}

疲れ試験は, すべて容量 $25 \mathrm{t}$ の油圧サーボ式疲労試 験機を用い, 繰り返し速度毎分 600 回の定荷重振幅で行 った. 応力振幅 $\sigma_{r}$ は, 原則として $\sigma_{r}=177 \mathrm{MPa}$ と $\sigma_{r}$ $=245 \mathrm{MPa}$ にし, 必要に応じて他の応力振幅も追加し た. 応力比 $R$ は, 0.1 とした.

疲れ亀裂の確認には，銅線法を用い，亀裂発生点を明 確にするため, 浸透性のよい塗料によるマーキングと, ビーチマーク法を併用した。 まず, 疲れ試験前に, 止端 部に, 直径 $0.04 \mathrm{~mm}$ の銅線を約 $1 \mathrm{~mm}$ 間隔に格子状に 貼った，疲れ亀裂が生じると，その開口変位によって銅 線が切断するので, それを電気的に感知して疲労試験機 を止めることができる. 本実験の例では, 亀裂が比較的 小さいとき（約 $0.2 \mathrm{~mm} \sim 0.5 \mathrm{~mm}$ の梁さ）に，自動的 に試験機を止めることができた。また，そのとき，浸透

Table 2 Mechanical Properties and Chemical Composition of Steels.

\begin{tabular}{|c|c|c|c|c|c|c|c|c|c|c|c|c|}
\hline \multirow{2}{*}{ Specimens } & \multirow{2}{*}{ Steel } & \multirow{2}{*}{$\begin{array}{c}\sigma_{y} \\
(\mathrm{MPa})\end{array}$} & \multirow{2}{*}{$\begin{array}{c}\sigma_{u} \\
(\mathrm{MPa})\end{array}$} & \multirow{2}{*}{$\begin{array}{c}\varepsilon \\
(\%)\end{array}$} & \multicolumn{8}{|c|}{ Chemical Composition (\%) } \\
\hline & & & & & $\mathrm{C}$ & $\mathrm{Si}$ & $\mathrm{Mn}$ & $\mathbf{P}$ & $\mathrm{S}$ & $\mathrm{Cu}$ & $\mathrm{Cr}$ & $\mathrm{V}$ \\
\hline$T$ & SMA 50 & 420 & 550 & 18 & 0.17 & 0.25 & 1.04 & 0.018 & 0.009 & 0.28 & 0.44 & 0.036 \\
\hline $\mathrm{N}$ & SMA 50 & 390 & 520 & 25 & 0.13 & 0.39 & 0.78 & 0.020 & 0.008 & 0.27 & 0.39 & - \\
\hline $\mathrm{E}$ & SM 50 & 360 & 540 & 27 & 0.15 & 0.35 & 1.26 & 0.21 & 0.06 & - & - & - \\
\hline
\end{tabular}

T, E : According to mill sheet, $\mathrm{N}:$ Measured. 


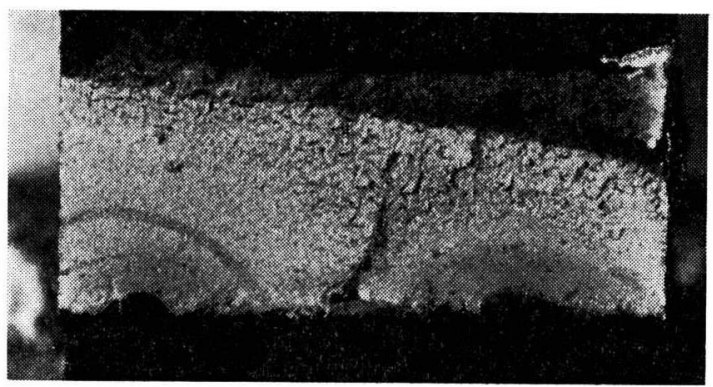

(a)

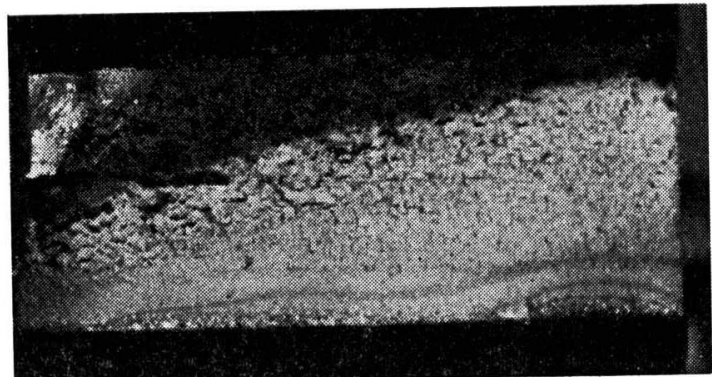

(b)

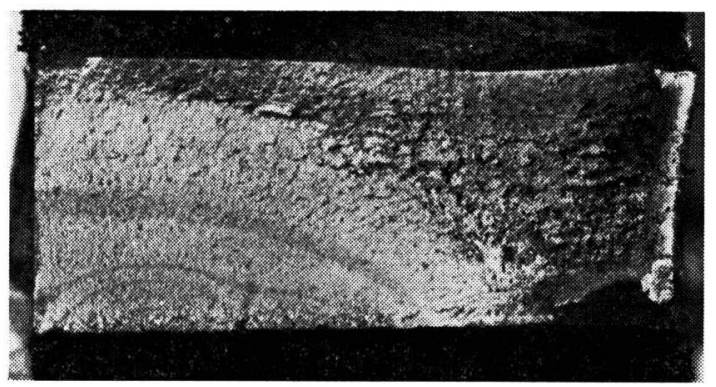

(c)

Photo 1

性のよい速乾性の塗料を溶接止端部に塗って, その時点 で存在した亀裂をマークした.さらに, 亀裂進展の様子 を追跡するため, ある一定繰り返し数ごとに, 最大応力 を一定にしたまま, 応力振幅を $1 / 2$ にして, 疲れ破面に ビーチマークを残すようにした。こうした方法により， 亀裂深さ $0.2 \mathrm{~mm}$ 程度までの微小な亀裂, およびそれ らの発生点を確認できた. Photo 1 には, 疲れ破面 に残されたマーキングとビーチマークの例を示す.

\section{（3）隅肉溶接止端形状の測定}

溶接止端形状の測定法の概略を, Fig. 2 に示寸. 疲れ試験に先だち, 歯型をとるのに用いる印象材を用 いて, 亀裂発生の予想される止端部 4 か所の型をと る. 疲れ亀裂が実際に発生した点が，前述のマーキン グやビーチマーク法によって求められるので, その点 を型にマークしたのち, 小刀を用いて亀裂発生点近傍 の断面を切り出す. この型は, 約 $0.3 \mathrm{~mm}$ の厚さまで

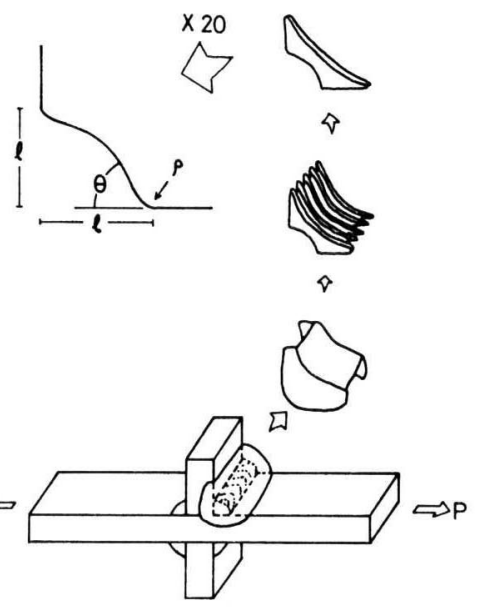

Fig. 2 Schematic view of measurement of fillet weld toe profile.

分割できた. この型の側面を, 拡大投影機で 20 倍に拡 大して, 止端半径 $\rho$ と止端角 $\theta$ を測定した. Fig. 3 に 示すよらに 0 は, 20 倍に拉大した状態で, $5 \mathrm{~mm}$ 間隔 で同心円を描いたスケールを押しあてて, それと一番近 いものとした. また, $\theta$ については, 上述の型を 20 倍 に拡大した後, 分度器をあてて, $5^{\circ}$ 間隔に測定した. 一部の試験片については, 型をビードの長手方向に分割 して, $\rho$ と $\theta$, および脚長 $l$ 変化の様子も調べた.

\section{3. 疲れ亀裂発生点と隅肉溶接止端形状}

\section{（1）止端形状の板幅方向の分布}

溶接ビードに沿って, 止端半径 $\rho$, 止端角 $\theta$, 脚長 $l$ が変化する様子を Fig. 4 に示す. $\mathrm{T}$ と $\mathrm{N}$ の例を示し たが, 両試験片とも, 幅 $25 \mathrm{~mm}$ にわたって, $\rho, \theta, l$ が 大きく変化していることがわかる. $\mathrm{T}$ と $\mathrm{N}$ を比較する と，まず $\rho$ は， $\mathrm{N}$ が一般に大きな值を示している．と ころが，N では $\rho$ の変化が大きく, $\rho$ が $1 \mathrm{~mm}$ 以下に

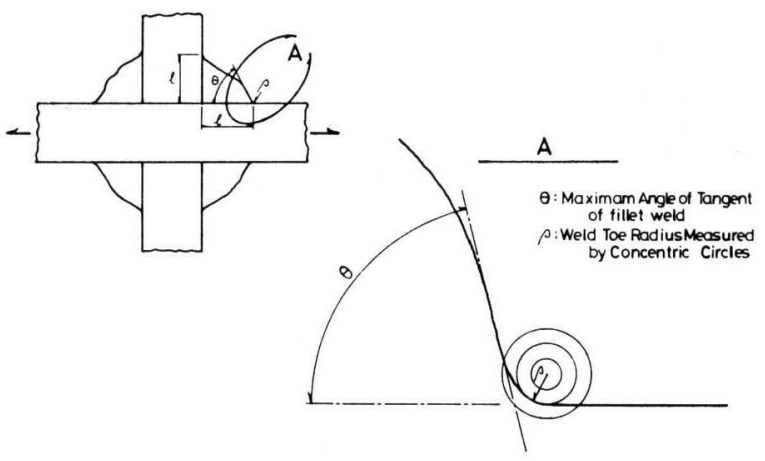

Fig. 3 Measurement of fillet weld toe angle and toe radius. 

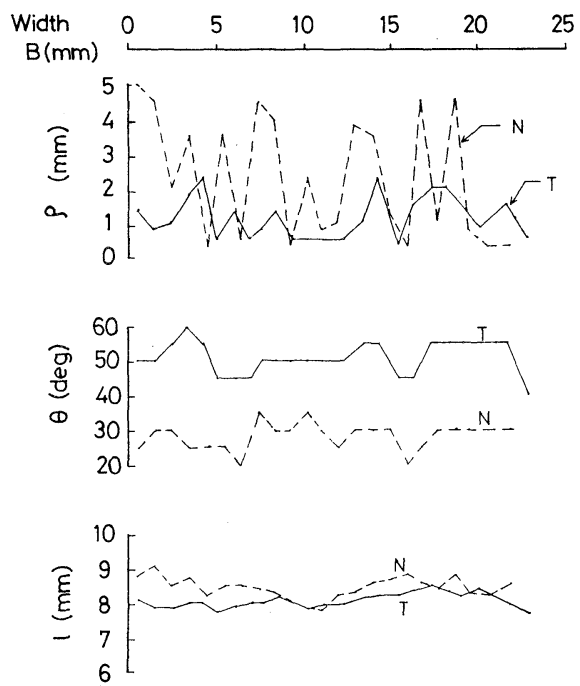

Fig. 4 Variation of weld toe frofile along toe of transverse fillet welds.

なる点が数か 所あり， $\rho$ 小さい部分 だけに注目 する と，両者は，よく似た傾问を示していることになる.

$\theta$ は, $\mathrm{T}$ が約 $50^{\circ}$ であるのに対して, $\mathrm{N}$ は $30^{\circ}$ 近辺 でばらついており，Nの止端角が比較的小さいことが わかる. また, $l$ は, $\mathrm{T}$ では目標とした脚長 $l=6 \mathrm{~mm}$ より一般に大きな值が得られ，7〜9 $\mathrm{mm}$ の範囲で変化 している. 実橋から切り出した $N$ は, 板厚から推定し て $l=6 \mathrm{~mm}$ を目標としたと思われるが，Tとほぼ同様 の傾向を示した.

\section{（2）疲れ亀裂が発生した点の止端形状}

次に, 実際に疲れ亀裂が発生した点の止端半径 $\rho_{c}$ と

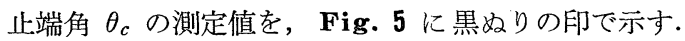

Fig. 5 では, 縦軸に $\theta_{c}$ を, 横軸に $\rho_{c}$ をとり, 比較 のために, 亀裂発生点以外での $\rho$ と $\theta$ の測定值を白ぬ きの印で示した. $\mathrm{T}, \mathrm{N}, \mathrm{E}$ ともに, $。$ が $0 \sim 5 \mathrm{~mm}$ の

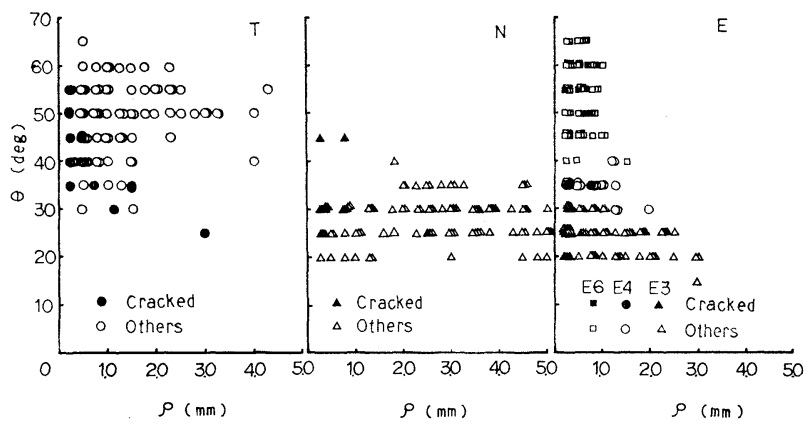

Fig. 5 Comparison between typical fillet weld toe profiles (open symbols) and one at which fatigue cracking is developed (solid symbols).
範囲で大きくばらついているにもかかわらず，疲れ亀裂 は, $\rho_{c}$ が $0 \sim 1 \mathrm{~mm}$ の比較的狭い範囲で発生しているこ とがわかる. これに反して， $\theta_{c}$ の分布は， T, N , E と もに, $\theta$ の示す分布と同じ範囲でばらついており, 疲れ 亀裂の発生は， $\theta$ より $\rho$ の影響を受け， $\theta$ の大小を問 わず $\rho$ の小さ所で発生することが推察された.

\section{（3）確認された亀裂形状とその近傍の $\boldsymbol{K}_{T}$ の分布}

隅肉溶接止端部の応力集中係数 $K_{T}$ は，実測された 隅肉溶接の形状から，Heywood・西田の式(10)を用いて計 算されることが多い ${ }^{81,11)}$. Fig. 1 に示す隅肉溶接で は， $\rho, \theta, l$ と板厚 $t$ を用いて，次式で計算される.

$$
K_{T}=1+f(\theta) \cdot(\alpha-1)
$$

ただし，

$$
\begin{array}{r}
\alpha=1+[1 /(2.8 B / b-2) \cdot l / \rho]^{0.65} \ldots \ldots . \\
f(\theta)=\left[1-\exp \left\{-0.9(B / l)^{1 / 2} \cdot \theta\right\}\right] / \\
{[1-\exp \{-0.45(B / l) \cdot \pi\}] \cdots}
\end{array}
$$

また, $B=t+l, b=t / 2$ である.

そこで, 疲れ亀裂が発生した点の近傍の $K_{T}$ を式 （1）（3）を用いて計算し，マーキングにより確認され た疲れ亀裂の形状を並べて, 試験片ごとに Fig. 6 に示 す. 亀裂形状の下に示す記号は, 試験片番号である. $K_{T}$ の分布の様子や, 確認された亀裂形状に大きなばら つきがあるが，一般に，亀裂発生点の近傍では，高い応 力集中，すなわち $K_{T}$ が上に凸の分布を示しているこ とがわかる．ただし， $K_{T}$ の值そのものは，亀裂発生点 を $K_{T}$ の分布の最深部と仮定すると, 1.5 から 3.5 程 度までばらついており, 亀裂発生点の $K_{T}$ の值に大き なばらつきがあることがわかった。

また， $K_{T}$ の分布と亀裂形状については， $K_{T}$ の分布 が上に凸で，その部分に独立した山を形成するよらに変 化している場合には, 半円形に近い亀裂が発生している ようである.これに対して， $K_{T}$ の高い部分が広い範囲 にあるか，ピークが接近していくつか連続する場合には

偏平に近い亀裂形状を示している。これは, $K_{T}$ の 高い部分の幅が大きいと, 刍裂が早く幅方向に進 展することや ${ }^{9)}, K_{T}$ の高い部分に発生した複数 の亀裂が，順次粼接した亀裂と合体してゆくこと などがその理由と考えられる。

\section{（4）亀裂の形状の変化}

前述したように, 亀裂の発生が確認された時点 で，その亀裂の形状をマーキングすることを試み た、このマークされた亀裂は, Photo 1 にみら れるように半棈円形をしていることが多い.そこ で, この亀裂の深さ $a(\mathrm{~mm})$ と半幅 $b$ の比 $a / b$ を縦軸に， $a$ を板厚 $t$ で無次元化した $a / t$ を横 
軸にとって，片対数軸上に示すと Fig. 7 のようにな る.この亀裂は, 亀裂進展の過程のある時点の形状を示 すもので, $a=0.2 \mathrm{~mm}$ 程度から $a \simeq 3 \mathrm{~mm}$ の範囲の亀 裂がマークされている. 亀裂形状 $a / b$ は， $a / b=0.2 \sim$

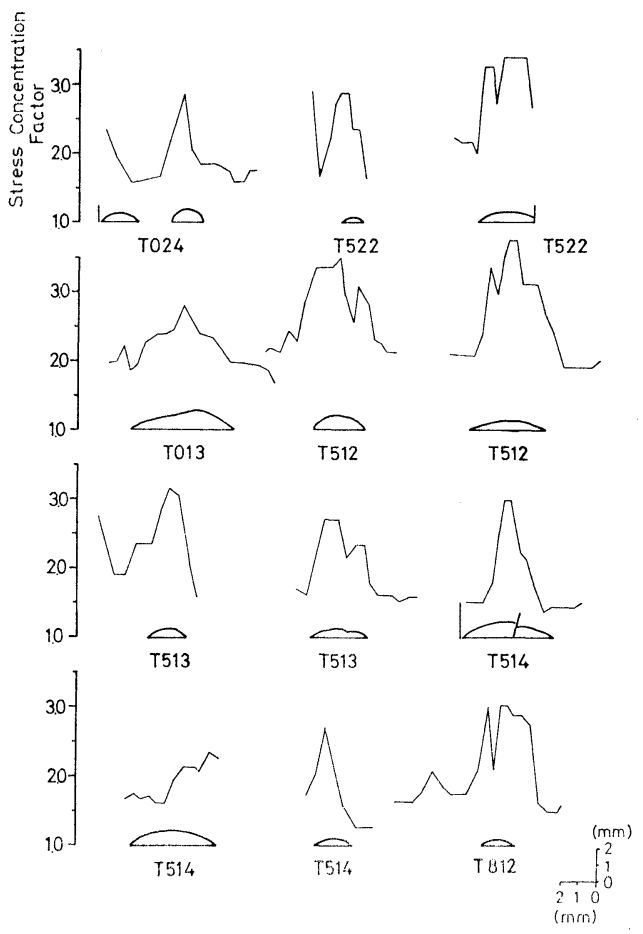

(a)

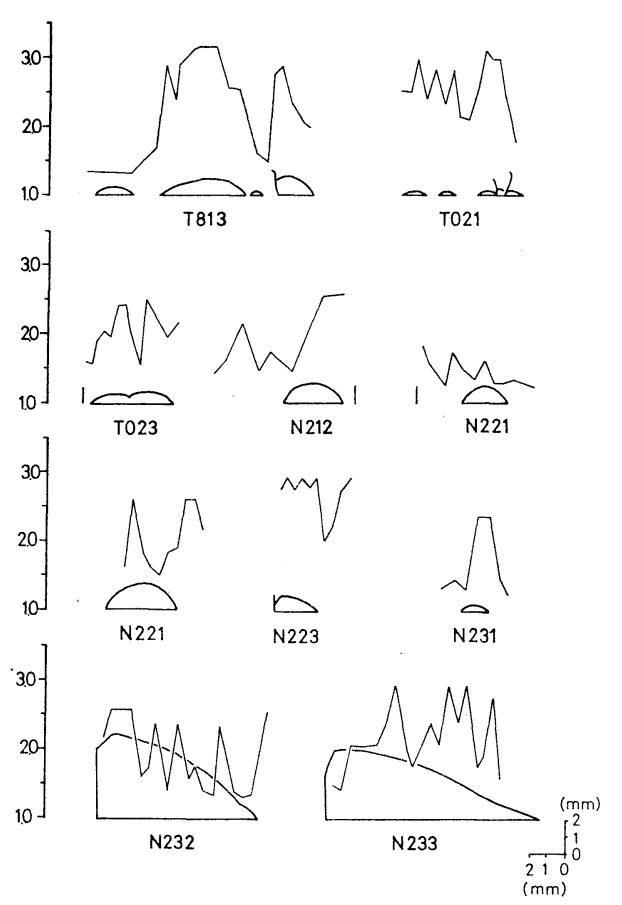

(b)
0.8 程度まで分布しており,このデータからは試験片の 種類による亀裂形状の差はみられなかった.

さらに,この試験では,ビーチマーク法によって亀裂 の形状の変化も追跡した (Photo 1 参照). このビーチ マークの形状，すなわち， $a / b$ と $a / t$ の関係を Fig. 8 に示す. 図では, 同一の亀裂については, 細線で結んで ある.したがって, $a / t$ の最小のものが, 最初に確認さ れた亀裂であり, 通常 2,3 個のビーチマークが測定さ れた.これらの結果をみても, 最初に確認された亀裂形 状のばらつきはもとより, 亀裂進展中もその形状の変化 に大きなばらつきがある.また, Fig. 8 a) にもみられ るように， $\theta$ を変えたことによって, 確認された亀裂の 形状や, その進展挙動に規則性があるとはいいがたい. ところが, いずれの場合も, 亀裂が進展してゆくに従っ $\tau$, 亀裂形状 $a / b$ が, $a / b=0.3 \sim 0.5$ に収束する傾向を 示している. 同様に, Fig. 8 の N では, たまたまビー チマークの残った試験片の $a / b$ は大きい（半楕円形に 近い）ものが多かったが，いずれも $a / b=0.4 \sim 0.6$ あ たりに収束してゆ!傾向を示した.このような傾向は, 文献 9）に示された解析による亀裂形状変化の傾向と定 性的に一致する.一般に疲れ亀裂の進展寿命は, 疲れ亀 裂が小さい間にその大半が費やされることが知られてい る $^{9,14)}$. Fig. 6 8 に示すように, 隅肉溶接止端部に 発生する亀裂の形状は, それが小さいとき（たとえば $a<1 \mathrm{~mm}$ ) のばらつきが大きく, 亀裂形状が一義的に
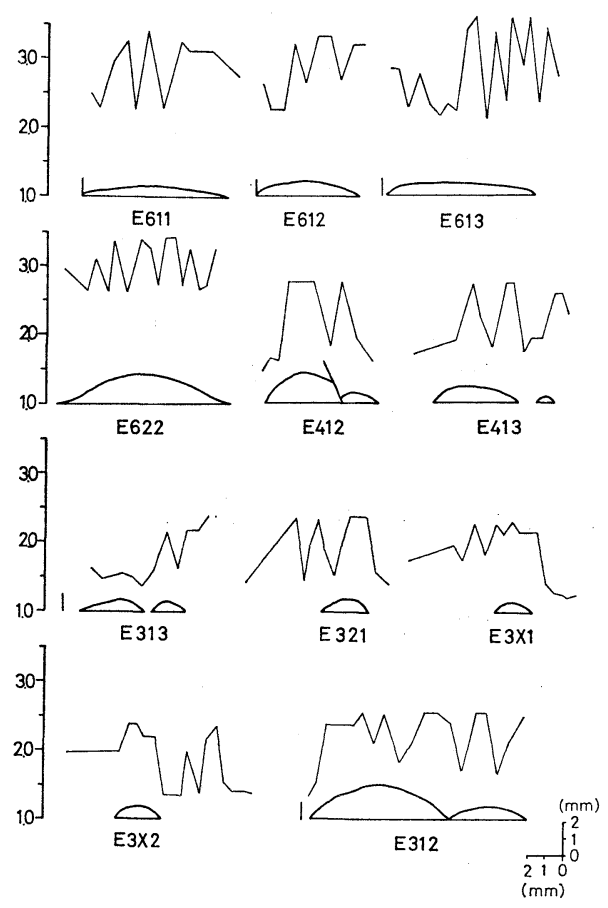

(c)

Fig. 6 Dye-marked crack shapes and stress concentration factors near the cracks. 


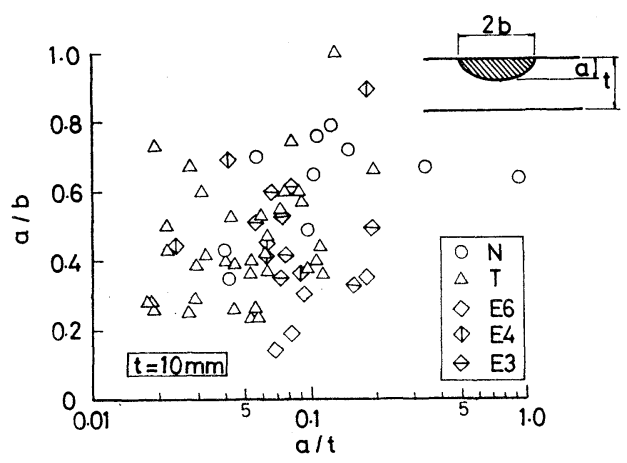

Fig. 7 Dye-marked crack shapes, $a / b$, and depth, $a / t$, of $\mathrm{T}, \mathrm{N}$ and $\mathrm{E}$ specimens.

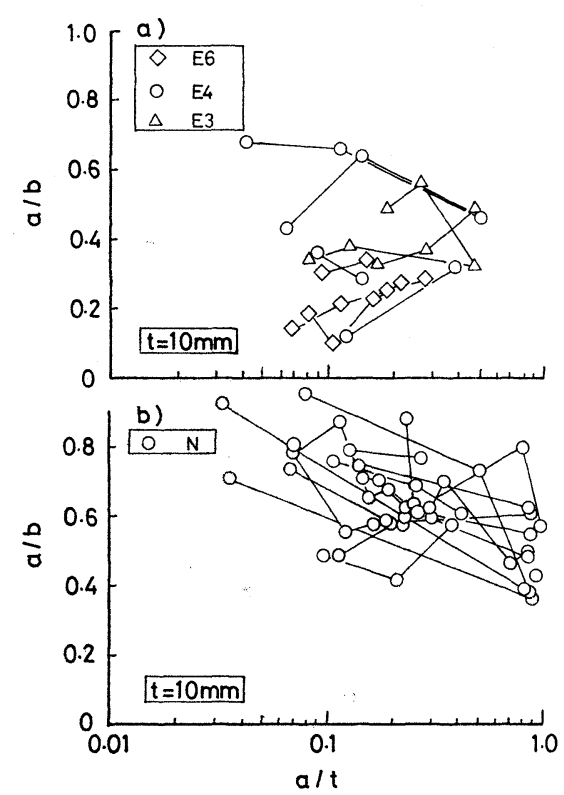

Fig. 8 Variation of crack shapes measured from dye-marking and beach-marking.

決まらない, したがって, 設計では, 実験において観察 された亀裂形状を用いるか，それまで観察された亀裂形 状の上・下限值 ${ }^{9}$ を用いる必要がある.

\section{4. 隅肉溶接止端形状と疲労寿命}

\section{（1）疲労寿命 $N_{f}$ の比較}

疲れ試験は，Tを 24 本， $\mathrm{N}$ を 31 本， E を 21 本実施した. その疲労寿命 $N_{f}$ と作用 応力振幅 $\sigma_{r}$ の関係を Fig. 9 亿示す. また， 破断した試験片の $\sigma_{r}-N_{f}$ 線図を, $\log N_{f}=$ $A-B \log \sigma_{r}$ と仮定して, 最小 2 乗法で計算 して図中に実線で示した. Table 2 には, このようにして計算した $\sigma_{r}-N_{f}$ 線図.(係数
A と B), 標準偏差 (s.d.), $10^{6}$ 回時間強度を示寸. 比 較を容易にするために， $\sigma_{r}=177 \mathrm{MPa}$ と $245 \mathrm{MPa}$ を 中心に実験を行っているが，図に示されるように，同一 応力レベルで実験しても， $N_{f}$ にかなりのばらつきがあ ることがわかる.

まず，Tでは，リブの溶接前に導入された圧縮塑性ひ ずみの影響が問題になるが，T 0 (無加工)，T 5 (5\% 圧縮塑性ひずみ)，T８（8\% 圧縮塑性ひずみ）間には $N_{f}$ に有意な差はみられない，塑性加工の影響があった にしても, その後のリブの溶接時の熱影響や, 隅肉溶接 止端の応力集中の影響が大きく, $N_{f}$ の差として現われ てこなかったものと思われる。

$\mathrm{N}$ は， 5 年間無塗装で大気暴露された実橋の腹板の垂 直補剛材から採取した試験片で, 表面がち密なさびに覆 われていた．このさびを除去すると，鋼材表面は，圧延 したままの鋼材より粗くなっており，微少なピットが多
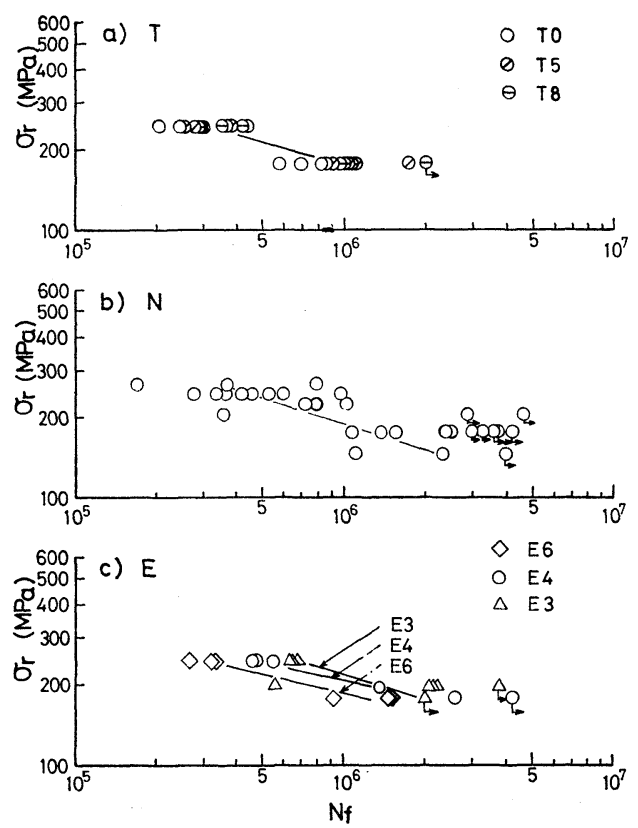

Fig. 9 Fatigue test results of all test specimens. $\left(\sigma_{r}-N_{f}\right.$ diagrams)

Table 3 Summary of Fatigue Test Results.

\begin{tabular}{c|c|c|c|c|c|c}
\hline \multirow{2}{*}{ Specimens } & \multirow{2}{*}{$\begin{array}{c}\text { No. of } \\
\text { Tests }\end{array}$} & $\begin{array}{c}\text { No. of } \\
\text { Run-out }\end{array}$ & \multicolumn{2}{|c|}{ Regression Coefficient } & $\begin{array}{c}\text { Fatigue } \\
\text { St. at 10 } \\
\text { (MPa) }\end{array}$ \\
\cline { 3 - 7 } T 0 & 8 & 0 & & B & s.d. & \\
T 5 & 8 & 0 & 13.7767 & -3.4696 & 0.1065 & 174 \\
T 8 & 8 & 1 & & & & \\
\hline N & 31 & 8 & 13.0078 & -3.0659 & 0.2016 & 193 \\
\hline E 3 & 9 & 2 & 14.5986 & -3.6708 & 0.2056 & 220 \\
E 4 & 6 & 1 & 17.8943 & -5.1111 & 0.0404 & 212 \\
E 6 & 6 & 0 & 15.9393 & -4.3744 & 0.0821 & 187 \\
\hline
\end{tabular}

s.d. standard deviation 
数存在した. Fig. 9 b) に示す $\mathrm{N}$ のばらつきは, T や Eのばらつきより大きいのは，このさびによる鋼材表面 の粗さがその一因と思われる. N の疲れ強さは，106 回 時闆強度で比較すると， $\mathrm{T} よ り$ 約 $11 \%$ 高い，止端角 $\theta$ をコントロールした E では, $\theta=30^{\circ}$ の E 3 が $\theta=60^{\circ}$ の $\mathrm{E} 6$ より, $10^{6}$ 回時間強度で約 $18 \%$ 高い疲れ強さを 示している. Fig. 5 に示すように, T は $\theta=60^{\circ}, \mathrm{N}$ は $\theta=30^{\circ}$ 近辺に分布しているので， $\mathrm{T}$ と $\mathrm{N}$ の披れ強さ の差も，この止端角 $\theta$ の差によるものと思われる. た だし，TもNも，データのばらつきが大きく，このデー タのばらつきを考慮すると両者の疲れ強さに有意な差が あるとはいいがたい，

\section{（2）疲れ亀裂進展寿命 $N_{p}$ の比較}

疲労寿命 $N_{f}$ は, 疲れ亀裂が発生しある大きさにな るまでの繰り返し数 $N_{c}$ と, その亀裂が進展して破断に 至る繰り返し数 $N_{p}$ の和として定義できる.

$$
N_{f}=N_{c}+N_{p}
$$

実験では, マーキングやビーチマーク法によって, 疲労 寿命のうちのある段階の亀裂の大きさがわかっている. そこで破壊力学の手法9)を用いて，この亀裂から逆算し て $N_{p}$ を計算した. この場合, $N_{c}$ と $N_{f}$ の境界の亀 裂長さを, マーキングによる検出可能な亀裂長さとして $a=0.2 \mathrm{~mm}$ を選んだ9, 15). 破壊力学による $N_{p}$ の解析
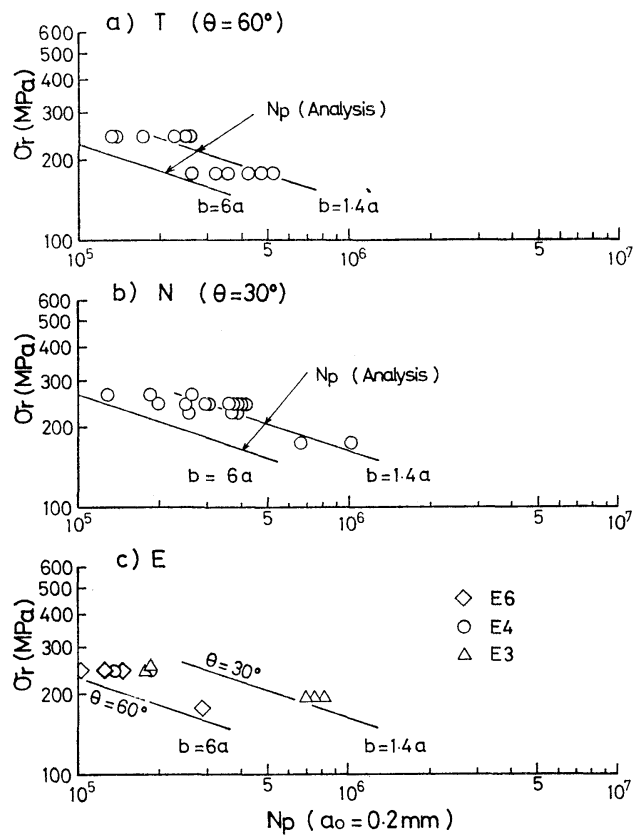

Fig. 10 Relationship between stress range, $\sigma_{r}$, and fatigue crack propagation life, $N_{p}$, of dyemarked specimens. $N_{p}$ is the number of cycles needed to propagate the crack from $a=0.2 \mathrm{~mm}$ to failure.
に用いた仮定は，文献 9）に示したものと同じである. まず，マーキングによって確認された亀裂長とその形 状を用いて， $a_{0}=0.2 \mathrm{~mm}$ からその亀裂に至るまでの繰 り返し数を計算する.この間の亀裂形状は，マークされ た亀裂形状と同じとした，また，止端角は，その試験片 の $\theta$ に最も近いものを, $\theta=30^{\circ}, 45^{\circ}, 60^{\circ}$ のらちから選 んで, 応力拡大係数の形状補正係数とした ${ }^{9)}$.このよう にして計算された $a_{0}=0.2 \mathrm{~mm}$ からマークされた亀裂の 大きさまでの繰り返し数と, 実験で求められたマーキン グから破断までの繰り返し数の和が $N_{p}$ になる.

Fig. 10 には，上述の方法で試験片ごとに計算した $N_{p}$ を示す．また，各図には，文献 9）で用いたのと同 様に, マーキングされた亀裂形状の範囲, すなわち $b=$ $6 a$ (偏平な亀裂) と $b=1.4 a$ (半円形に近い刍裂)を 用いて計算した $\sigma_{r}-N_{p}$ 線図を実線で示す.まず， T で は, 12 本の試験片について解析した結果, $N_{p}$ は $N_{f}$ の 40〜77\% になった. また, 亀裂形状の範囲を用いて 解析した $\sigma_{r}-N_{p}$ 線図の上・下限值が, 試験片ごとに解 析した $N_{p}$ をうまく代表していることがわかった。こ の場合, $\theta$ は $60^{\circ}$ と仮定した.

同様に, $\mathrm{N}$ についても， $N_{f}$ に比べて $N_{p}$ のばらつ きが小さい. 特に, Nは無塗装で大気暴露されていたた め鋼材表面が粗く，そのためか， $N_{f}$ のばらつきが大き い. $a_{0}=0.2 \mathrm{~mm}$ の刍裂が発生すると, それ以降の $N_{p}$
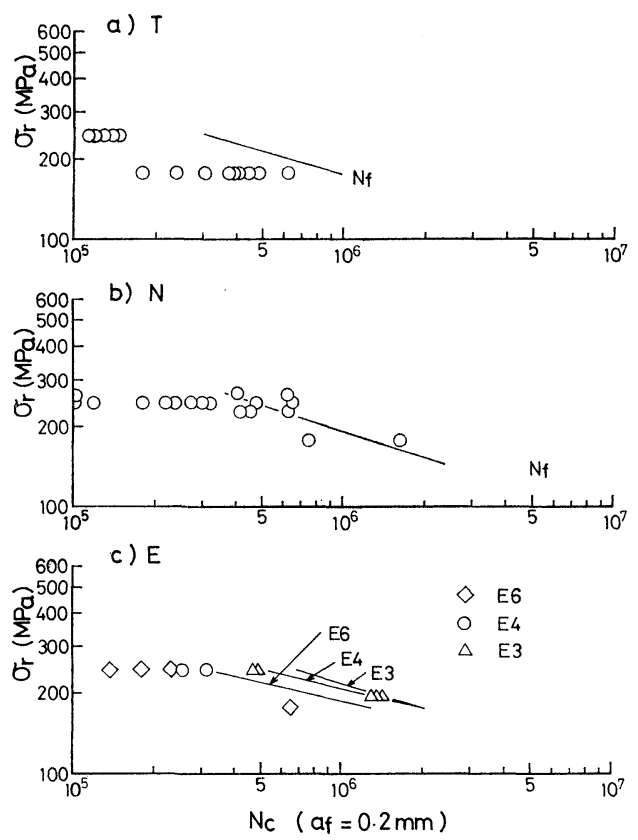

Fig. 11 Relationship between stress range, $\sigma_{r}$, and fatigue crack initiation life, $N_{c}$, of dyemarked specimens. $N_{c}$ is defined as the number of cycles needed to initiate and propagate the crack to $a=0.2 \mathrm{~mm}$. 
のばらつきは比較的小さくなるのは興味ある結果と思わ れる。なお， $N_{p}$ の $N_{f}$ に対する割合は， $N_{f}$ がばらつ くので 23〜76\% の間にばらつくことがわかった.

止端角 $\theta$ をコントロールした $\mathrm{E}$ では, データの数が 少ないが，E６より E 3 の $N_{p}$ が大きい結果が得られ た. 解析でも，同じ亀裂形状を仮定すると， $\theta=60^{\circ}$ に 対して $\theta=30^{\circ}$ では， $a_{0}=0.2 \mathrm{~mm}$ からの $N_{p}$ が約 $38 \%$ (10 回時間強度で約 $11 \%)$ の向上が得られた. E の $N_{p}$ が $N_{f}$ に占める割合は，29 48\% 程度であったので, 解析から得られた $N_{p}$ の向上も, それほど $N_{f}$ の増加 の要因になっておらず, 後述するように $N_{c}$ の増加によ って $N_{f}$ が増加したと考える方が妥当であろう。

\section{（3）疲れ亀裂発生寿命 $N_{c}$ の比較}

試験途中の亀裂がマークされた試験片ごとに， $N_{p}$ が 計算できたので, 次に $N_{c}=N_{f}-N_{p}$ の関係を用いて, 試験片ごとに $N_{c}$ を計算して, Fig. 11 に示す. ここ では，したがって $N_{c}$ を，疲れ亀裂が発生して $a_{f}=0.2$ $\mathrm{mm}$ に達するまでの繰り返し数として定義したことにな る.また, Fig. 11 では, 比較のために $\sigma_{r}-N_{f}$ 線図 (Fig. 9) を示す.

$\mathrm{T}, \mathrm{N}, \mathrm{E}$ ともに， $N_{c}$ のばらつきは $N_{p}$ のぼらつき より大きい. 特に, 鋼材表面の粗さが目立つNでは, $\sigma_{r}$ $=245 \mathrm{MPa}$ で試験した試験片の $N_{c}$ が, $4 \times 10^{4}$ 回から $6 \times 10^{5}$ 回までばらつき，これが $N_{f}$ のばらつき (Fig. 9）の原因になったものと思われる. また， $\theta$ をコント ロールした E では, $N_{p}$ の $N_{f}$ に占める割合が小さい こともあって，止端角が $N_{f}$ に及ぼす影響は，おもに $N_{c}$ の差によるものと思われる.

\section{5. まと め}

隅肉溶接止端形状が, 継手の疲れ強さに及ぼす影響を 検討するために, 経歴の異なったリブ十字形隅肉溶接継 手 76 本の疲れ試験を行った. 試験片は, 圧縮塑性加工 の影響を調べるために，軸方向に $0 \%$ (無加工), $5 \%$, $8 \%$ の圧縮塑性ひずみを与えた試験片 (T)， 5 年間ほ ど無塗装で大気暴露された実橋から切り出した試験片 $(\mathrm{N})$ ，および止端角 $\theta$ を $30^{\circ}, 45^{\circ}, 60^{\circ}$ にコントロール した試験片（E）である. 実験では, あらかじめ隅肉溶 接の型をとって拄き, 亀裂発生点の止端形状を求めた. また, 疲れ試験中の亀裂の大きさを確認するため, 塗料 によるマーキングやビーチマーク法を併用した．これか ら得られた亀裂の大きさや形状を用いて, 疲れ亀裂発生 寿命 $N_{c}$ と疲れ亀裂進展寿命 $N_{p}$ それぞれに及ぼす止 端形状の影響について評価した. なお， $N_{c}$ と $N_{p}$ の境 界は, 便宜上, マーキングによって検出可能な亀裂の大
きさ $a=0.2 \mathrm{~mm}$ を目安にした.

得られた結果をまとめると次のようになる。

（1）疲れ亀裂は, 隅肉溶接止端に沿って, 応力集中 率 $K_{T}$ の大きい箇所に発生している. また, 止端角 $\theta$ の 大小にかかわらず，止端半径 $\rho$ が $1 \mathrm{~mm}$ 以下の小さい 所で亀裂が発生している.

（2）亀裂発生点近傍の止端形状から計算される $K_{T}$ の分布と, 発生する亀裂形状をみると, $K_{T}$ が独立した 山を作るよらな分布を示すとき, 半円形に近い亀裂が観 察された.これに反し， $K_{T}$ の高い部分が続くか，隣接 したピークがあると偏平な亀裂が発生する傾向がわかっ た.

（3）マーキングによって確認された亀裂と $\theta$ には, 明瞭な相関がみられなかった.ビーチマークから求めら れた亀裂形状の変化では, 亀裂が大きくなってゆくに従 って，㐫る範囲に収束する傾向がみられた．

(4) $N_{f}$ はばらつきが大きいが, $\theta=60^{\circ}$ に比べて $\theta$ $=30^{\circ}$ の $N_{f}$ が増加する傾向がみられた. 特に, $\theta$ をコ ントロールした E では, $N_{f}$ の差が顕著にみられた.

（5） マークされた亀裂の大きさを用いて， $a_{0}=0.2$ $\mathrm{mm}$ の亀裂が進展して破断に至る $N_{p}$ を, 破壊力学の 手法を用いて計算し比較した。 こうして計算した $N_{p}$ は, 一般に $N_{f}$ のばらつきより小さく, また, 測定さ れた亀裂形状の範囲 ${ }^{9)}$ を用いて計算した $\sigma_{r}-N_{p}$ 線図と よい相関を示した。

(6) $N_{c}=N_{f}-N_{p}$ から計算された $N_{c}$ を比較した 結果, 鋼材表面の粗い N では, $N_{f}$ のばらつきがおも に $N_{c}$ のばらつきによることがわかった。 また， E で は， $\theta$ を変えたことによる $N_{f}$ の差が，おもに $N_{c}$ の 差に起因することが推察された。

謝辞：本研究に用いた試験片のうち, TとEはト ピー工業豊橋製造所に製作をお願いし，Nの鋼材は，川 崎製鉄構造研究所より譲渡された. トピー工業技術研究 所の青木尚夫氏, 長井憲一氏, 川崎製鉄の佐藤政勝氏に は, 実験を通じて大変お世話になった。また, 疲れ試験 には, 馬場千尋 (現・横河橋梁), 三輪友夫 (現 - 名古屋 市), 渡辺博喜 (現・愛知県), 進藤弘之 (現・静岡県), 村山 真 (名大大学院) の諸氏に協力していただいた. ここに記して厚く感謝の意を表します.

\section{参 考文 献}

1) Albrecht, P. and K. Yamada : Rapid Calculation of Stress Intensity Factors, Proc. of ASCE, Vol. 103, No. ST 2, pp. 377 389, Feb., 1977.

2) Maddox, S.J. : A Fracture Mechanics Analysis of the Fatigue Behaviour of a Fillet Welded Joint, Welding Research International, Vol. 6, No. 5, 1976.

3) Rolfe, S.T. and J.M. Barsom : Fracture and Fatigue 
Control in Structures, Application of Fracture Mechanics, Prentice-Hall Inc., 1977.

4) Yamada, K. and P. Albrecht : Practical Aspects of Fatigue Analysis of a Weldment, Fracture 1977, Vol. 2, Proc. of Fourth International Conference on Fracture, pp. 959 966, 1977.

5）太田省三郎・工藤松一：すみ肉溶接継手の止端の研削拉 よびワイヤーピーニングによる疲れ強さ向上（第 1 報）, 溶接学会誌, 第 49 巻, 第 2 号, pp. $28 \sim 34$, 昭和 55 年 2 月.

6）鎌倉将英, ほか：SM 50 B リブ十字すみ肉溶接継手の疲 れ特性におよぼす寸法効果, 溶接学会誌, 第 48 巻, 第 12 号, pp. 46 50, 1979 年 12 月.

7）二瓶正俊, ほか：被覆アーク溶接継手の疲れ強さに及ぼ す溶接止端形状および溶接条件についての統計的解析, 日本造船学会論文集, 第 146 号, pp. 413 426, 1979 年 11 月.

8）日本鋼構造協会疲労小委員会：溶接継手の止端研削によ る疲れ強さ向上法, JSSC, Vol. 12, No. 126, pp. 1 22, 1976 年.
9）山田健太郎・牧野時則・菊池洋一：横リブ十字すみ肉溶 接止端部に 発生する疲労亀裂の解析, 土木学会論文報告 集, 第 292 号, pp. 1 11，1979 年 2 月.

10）西田正孝：応力集中, 森北出版, p. 50, 1967 年.

11）河合末男, ほか：高張力鋼溶接継手の疲労強度に及ぼす ビード止端処理の効果, 溶接学会誌, 第 48 巻, 第 9 号, pp. 44 51, 1979 年 9 月.

12）河合末男・鯉㴊興二：高い平均応力下の溶接継手の平面 曲げ疲れ強さに及ぼすグラインダ仕上及びピーニングの 効果, 溶接学会誌, 第 44 巻, 第 7 号, 1975 年 7 月.

13）池田一夫, ほか：高張力鋼すみ肉溶接継手の疲れ強さの 改善, 溶接学会誌, 第 44 巻, 第 2 号, 1975 年 2 月.

14）田島二郎, ほか：溶接構造と疲労, 土木学会誌, Vol. 664 , pp. 1 10, 昭和 56 年 4 月.

15）山田健太郎・牧野時則, ほか : 疲労亀裂の進展挙動に注 目したガセット継手の疲労強度解析, 土木学会論文報告 集, 第 303 号, pp. 31 41, 1980 年 11 月.

16）竹名興英・岸本良孝・伊藤文夫：リブ十字継手の疲労許 容応力，本四技報，No. 16, pp. 2 4, 1981 年 4 月.

(1981.7.13 - 受付) 